REVIEW

\title{
Agricultural watershed modeling: a review for hydrology and soil erosion processes
}

\author{
Modelagem em bacias hidrográficas agrícolas: uma revisão para \\ hidrologia e processos de erosão do solo
}

\author{
Carlos Rogério de Mello ${ }^{1 *}$, Lloyd Darrell Norton², \\ Leandro Campos Pinto ${ }^{4}$, Samuel Beskow ${ }^{3}$, Nilton Curi ${ }^{4}$
}

\author{
${ }^{1}$ Universidade Federal de Lavras/UFLA, Departamento de Engenharia/DEG, Lavras, MG, Brasil \\ 2Purdue University, USDA-ARS National Soil Erosion Research Laboratory, West Lafayette, IN, USA \\ ${ }^{3}$ Universidade Federal de Pelotas/UFPel, Pelotas, RS, Brasil \\ ${ }^{4}$ Universidade Federal de Lavras/UFLA, Departamento de Ciência do Solo/DCS, Lavras, MG, Brasil \\ *Corresponding author: crmello@deg.ufla.br \\ Received in november 5, 2015 and aproved in december 18, 2015
}

\begin{abstract}
Models have been used by man for thousands of years to control his environment in a favorable way to better human living conditions. The use of hydrologic models has been a widely effective tool in order to support decision makers dealing with watersheds related to several economic and social activities, like public water supply, energy generation, and water availability for agriculture, among others. The purpose of this review is to briefly discuss some models on soil and water movement on landscapes (RUSLE, WEPP, GeoWEPP, LASH, DHSVM and AnnAGNPS) to provide information about them to help and serve in a proper manner in order to discuss particular problems related to hydrology and soil erosion processes. Models have been changed and evaluated significantly in recent years, highlighting the use of remote sense, GIS and automatic calibration process, allowing them capable of simulating watersheds under a given land-use and climate change effects. However, hydrology models have almost the same physical structure, which is not enough for simulating problems related to the long-term effects of different land-uses. That has been our challenge for next future: to understand entirely the hydrology cycle, having as reference the critical zone, in which the hydrological processes act together from canopy to the bottom of aquifers.
\end{abstract}

Index terms: RUSLE; WEPP; GeoWEPP; LASH; DHSVM; AnnAGNPS.

\begin{abstract}
RESUMO
Modelos têm sido usados pelo homem há milhares de anos para controlar seu ambiente de uma maneira favorável para melhores condições de vida para os humanos. O uso de modelos hidrológicos tem sido uma ferramenta muito eficaz para apoiar os decisores que lidam com as bacias hidrográficas para subsidiar diversas atividades econômicas e sociais, como o abastecimento público de água, geração de energia, e a disponibilidade de água para a agricultura, entre outros. Objetivou-se, nesta revisão, discutir brevemente alguns modelos muito aplicados ao estudo do movimento da água e solos em paisagens (RUSLE, WEPP, GeoWEPP, LASH, DHSVM and AnnAGNPS), para fornecer informações sobre os mesmos, para auxiliar no entendimento adequado de problemas específicos relacionados com os processos de hidrologia e erosão do solo. Modelos têm sido alterados e avaliados de forma significativa nos últimos anos, com destaque para o uso de sensoriamento remoto, GIS e processo de calibração automática, permitindo aos mesmos que sejam capazes de simular bacias hidrográficas nas suas condições atuais de uso do solo e mudanças climáticas. No entanto, os modelos hidrológicos têm quase a mesma estrutura física, o que não é suficiente para simular problemas relacionados com os efeitos a longo prazo de diferentes usos do solo. Esse tem sido um dos principais desafios para o futuro: compreender inteiramente o ciclo hidrológico, tendo como referência a zona crítica, na qual os processos hidrológicos agem em conjunto a partir do dossel até a base dos aquíferos.
\end{abstract}

Termos para indexação: RUSLE; WEPP; GeoWEPP; LASH; DHSVM; AnnAGNPS.

\section{INTRODUCTION}

Models have been used by man for thousands of years to control his environment in a favorable way to better human living conditions. Early engineers used simple models to develop structures such as a lean to, a pyramid, a road through the jungle or an aqueduct to bring water. These were largely successful to allow humans to flourish in previously impossible environments. These were largely taught from person to person through the years and rarely written down except in by a few extraordinary individuals e.g. (Mulvaney, 1850). 
In relation to water, models are a way of predicting the behavior of water moving on landscapes for a number of problems facing society in the past and today. Flood predictions at various scales help us design structures and various infrastructures to keep people safe. Accurate predictions help us design facilities to serve as safe vessels for water storage, irrigation, navigation and also produce electricity among other things. The advent of computers that are cheap and widely available have greatly proliferated the occurrence of modelling in the physical sciences. This ease of being able to conduct modelling has almost made the endeavor a field of science on its own. To quote Phillip (1991): "I cannot resist quoting the dictum popularly attributed to Felix Franks, the British physical chemist: "Modelling is rather like masturbation - a pleasurable and harmless pastime just as long as you don't mistake it for the real thing". Therefore, one must be careful when blinding using the output of various models without understanding the inner workings and assumptions being made behind to computer screen for proper application in the real world.

In spite of these models do have a place especially involving the use of water as life cannot exist anywhere without access to sufficient safe and clean water for consumption. The first well known model related to water discharge was developed by Mulvaney (1850), who developed from observation a simple model to relate the amount of water leaving a small rural watershed based on the precipitation received in Ireland. This was later termed the rational method to related rainfall to runoff to streamflow and attributed to be the first such model. The model is very simple and its form is:

$\mathrm{Q}=\mathrm{C}$ IA

where, $\mathrm{Q}$ in the peak discharge, $\mathrm{C}$ is a constant, $\mathrm{I}$ is the rain intensity and $\mathrm{A}$ is the watershed area.

Of course, this is a highly simplified version of the rainfall-runoff process and does not account for the many variables that occur to cause variations such as antecedent moisture content, vegetation changes, event time-intensity relationships, etc. However, even with the limitations it is highly successfully used in engineering designs and still taught in classes today.

The purpose of this review is to briefly discuss some modern models on soil and water movement on landscapes to provide information on these models to help and serve in a proper understanding of particular problems related to hydrology and soil erosion processes.

\section{MODELS DESCRIPTION}

\section{Revised Universal Soil Loss Equation (RUSLE)}

The Universal Soil Loss Equation (USLE) has been widely applied in many countries as it is a practical tool to calculate the average annual soil erosion rate for different soils and weather conditions. Due to its simplicity, for running this model, there are consolidated databases available mainly for soils (natural vulnerability to erosion, covering, and management) and weather.

The model was structured based on a linear combination of the parameters more correlated with the soil water erosion process by Wischmeier and Smith (1978). These parameters were gathered after monitoring of runoff plots in the US and they can be separated into two types: active and passive erosion factors. The later are related to the soil susceptibility to erosion, which is represented by particle size distribution, organic matter content, weathering of the soils, parent material, type of clay minerals, biological activities, among other intrinsic elements. Beyond this factor, the soils vegetative cover, which is expressed by the land-use (the greater soil covering the lesser its susceptibility to erosion), and topographical characteristics, help to define the behavior of soil erosion by rain. The active factors are defined by the rainfall pattern (the intensity and kinetic energy of the rainfall events) that characterizes a coefficient known as rainfall erosivity $\left(\mathrm{EI}_{30}\right)$. However, to use USLE or RUSLE (its revised form) in agricultural lands, the active factors are estimated based on the annual average value of $\mathrm{EI}_{30}$ from at least 15-years of long-term rain data, defining, this way, the R-factor in the model (Mello et al., 2015). It means that USLE/RUSLE cannot be applied to simulate individual rainfall-runoff events.

Nevertheless, the USLE was not designed for application to watersheds because of their complex topographical conditions. To overcome this limitation, the model was revised by Renard et al. (1993), who proposed important improvements on the topographic factor (LS-factor) estimates, adjusting it to different terrains including steep ones and with different shapes (concave or convex curvature plan). At to LS-factor, it incorporated the flux of convergence impacts, which considered the runoff contribution from upstream to the downstream cells. For this new model, known as RUSLE3D, it is indispensable to use a GIS tool to create the necessary maps of the accumulated flux direction (LS-factor), land-use (C-factor), pedological units 
(K-factor) and rainfall erosivity (R-factor) making a combination of them by means of algebraic map. The output is a soil erosion map spatially distributed by cells whose size is defined according to the vertical resolution of the DEM used.

RUSLE3D model has been applied to develop soil erosion risk maps mainly in developing countries (Beskow et al., 2009; Durães; Mello, 2014; Oliveira et al., 2014; Segura et al., 2014; Tang et al., 2015; Zhou et al., 2008). With the advent of geospatial computer resources, its application has allowed generating an easier and more accurate soil erosion risk map, supporting the engineers to identify spatially areas more susceptible to erosion and then, to target soil conservation practices more adequate. Figure 1 presents an example of a soil erosion risk map development through RUSLE3D. This study was carried out by Oliveira et al. (2014) to a basin located in southern Minas Gerais State, Brazil.

For simulation of individual rainfall-runoff events, it is necessary to considers respective runoff and/or peak discharge instead of R-factor. The version that consider this possibility as known as Modified Universal Soil Loss Equation (M-USLE) has been applied embedded with the hydrological models, like in Soil Water Assessment Tool (SWAT) and AnnAGNPS, for simulation sediment transport in agricultural watersheds.
(1)
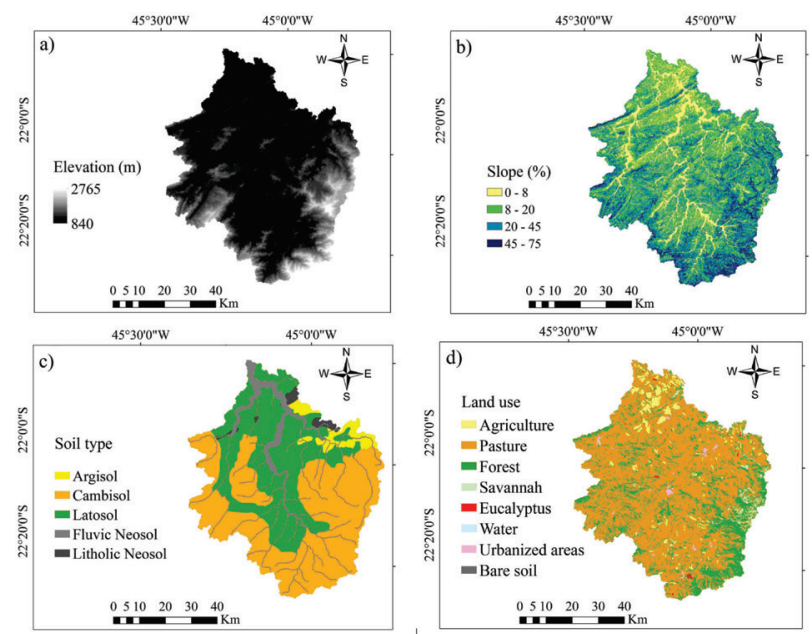

\section{(1) Basic maps for running RUSLE}

(2) RUSLE factors maps derived from the basic maps

\section{(3) Algebra map to} combine of factors maps

(4) Soil erosion risk map
(2)

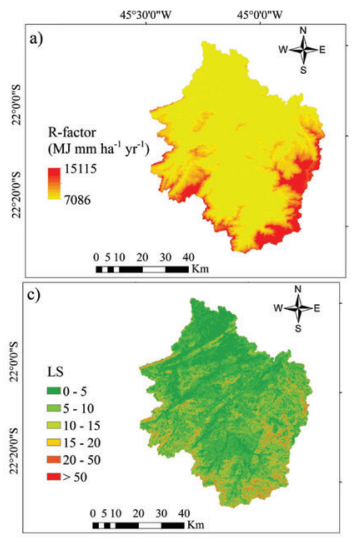

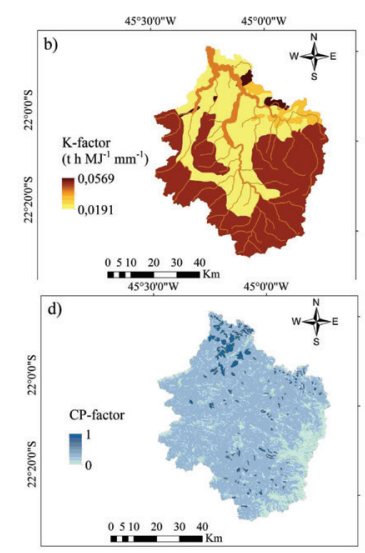

(4)

(3)

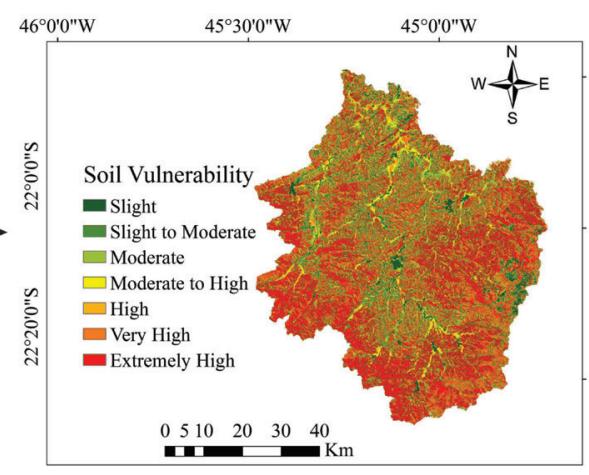

Figure 1: Soil erosion risk map development applied to the Verde River basin based on the RUSLE3D procedure (Oliveira et al., 2014). 


\section{Water Erosion Prediction Project (WEPP)}

The Water Erosion Prediction Project (WEPP) (Flanagan; Nearing, 1995; Flanagan et al., 2001; Laflen et al., 1991 ) is a physically based model for soil erosion prediction in agricultural areas, mainly in the USA. The model simulates runoff, soil erosion, sediment transport, and agrochemicals taking place these phenomena in rill and interrill areas.

This soil-erosion process-based model was developed by a joint effort of several federal agencies in USA and their cooperators (Deb; Shukla, 2011; Foster; Lane, 1987). The project of the model was initiated in 1985 to develop a new-generation water erosion prediction technology for use by federal action agencies involved with soil and water conservation and environmental planning and assessment to replace the USLE and RUSLE (Flanagan; Gilley; Franti, 2007).

Since the Universal Soil Loss Equation and its revised and modified versions ( $\mathrm{R}$ and $\mathrm{M}$-USLE) were used extensively to predict long-term average annual soil loss and could not easily be expanded to meet the needs of conservationists and environmental managers, the WEPP model was designed to address those applications that are not covered by the USLE family of models (Flanagan; Gilley; Franti, 2007; Foster; Lane, 1987). According to Flanagan, Gilley and Franti (2007), another problem related to the USLE model is associated with its low capability to estimate runoff, spatial locations of soil loss on a hillslope profile or within a small watershed, channel (rill) erosion, effects of impoundments, recurrence probabilities associated with specific erosion events, or watershed sediment yield, transportation or deposition. The WEPP model was framed to cover all of these needs, and to be an option to replace the empirical based erosion prediction technologies (Flanagan; Gilley; Franti, 2007).

Basically, WEPP is a continuous simulation computer program which predicts soil loss and sediment transport and deposition from overland flow on hillslopes, soil loss and sediment deposition from concentrated flow in small channels, and sediment deposition in impoundments (Fares, 2008). Regarding the model structure, WEPP includes, besides rill and interrill erosion models, climate, hydrology, daily water balance, plant growth and residue decomposition models along with irrigation components (Fares, 2008; Flanagan; Nearing, 1995; Foster; Lane, 1987).

\section{WEPP model components}

The WEPP model components are: climate, surface runoff, infiltration, percolation, evaporation, transpiration, rill and interrill erosion, erodibility and processes, sediment transport and deposition, soil consolidation, residue and canopy effects on soil detachment and infiltration, surface sealing, rill hydraulics, plant growth, residue decomposition, snow melt, frozen soil effects on infiltration and erodibility, climate and tillage effects on soil properties, effects of soil random roughness and contour effects, including the potential overtopping of contour ridges (Deb; Shukla, 2011; Flanagan; Nearing, 1995; Flanagan et al., 2001; Foster; Lane, 1987). Below, we made a brief description of WEPP model components described by Flanagan and Nearing (1995) and Deb and Shukla (2011).

\section{a) Erosion component}

Many soil parameters used in hydrological and erosion components are dynamic in terms of cultivation, soil weathering and historical rainfall and are adjusted automatically as a function of time of cultivation operations and hydrological processes.

Erosion components are embedded in the WEPP model which uses a closed-form solution to a steady-state form of the continuity equation applied to estimate the hillslope sediment movement and delivery. One of the advantages of WEPP is to separate the erosion processes into rill detachment as a function of excess flow shear stress and inter-rill detachment as a function of rainfall intensity (Deb; Shukla, 2011). In addition, the model estimates the transport capacity and sediment movement whether the flow capacity of the rill is greater than the sediment load; otherwise, the model estimates sedimentation of soil particles (Deb; Shukla, 2011; Flanagan; Nearing, 1995). WEPP also utilizes topography and land cover information to generate runoff as well as sediment yield and a soil loss estimation (Maalim et al., 2013).

\section{b) Climate component}

A climate database was developed stochastically by the CLIGEN weather generator model (Nicks; Lane; Gander, 1995), in which information on volume, duration, intensity and frequency of rainfall, maximum and minimum temperature, solar radiation and dew point for the location of interest are generated based on a historical series from the nearest weather station located in US territory. The information generated by CLIGEN was written in a climate file for later use by the WEPP model.

For the application of WEPP it is necessary to use daily climate data, which are not always easily available and, depending on this, CLIGEN is used to generate the necessary climate data base using the Markov Chain stochastic process (Zhang; Garbrecht, 2003). 


\section{c) Hydrology components}

The hydrological model embedded in WEPP calculates infiltration, overland flow and water balance, including evapotranspiration and deep percolation. Infiltration, and consequently, overland flow, are calculated based on Green-Ampt model, which is modified to varying intensities of rain and ponding time.

The approximate method used for calculation of runoff volume, peak runoff rate and runoff duration is carried out based on kinematic wave method for propagation of the flow in channels (Deb; Shukla, 2011), which is solved analytically by the Method of Characteristics (Eagleson, 1970).

\section{d) Plant growth}

The plant growth component estimates growth (above and below ground biomass production), senescence of plants and decomposition of plant residues (Deb; Shukla, 2011; Flanagan; Nearing, 1995). However, this WEPP component has undergone major revisions (Deb; Shukla, 2011).

\section{e) Soils}

The impacts of the tillage on various soil properties and model parameters are computed within the soils component of the WEPP. Many soil parameters used in hydrological and erosion components are dynamic in terms of cultivation, soil weathering and historical rainfall, and they are adjusted automatically as a function of time of cultivation, operations and hydrological processes (Deb; Shukla, 2011).

\section{Geo-spatial interface for WEPP (GeoWEPP)}

The Geo-spatial interface for WEPP (GeoWEPP) is an ArcView 3.x or ArcGIS 9.x extension that allows the use of a digital elevation model (DEM) and topographic maps to generate watershed configurations along with topographic inputs for the WEPP model (Renschler, 2003). Flanagan et al. (2013) described the mathematical approaches and interfaces that have been developed for GeoWEPP. With these new functions, WEPP application to watersheds has made the outputs more feasible.

GeoWEPP includes 3 news parts: GIS model; TOPAZ; and TopWEPP that further expanded its applicability. Yu, Zhang and Niu (2009) showed a short tutorial to these tools in GeoWEPP, wherein, TOPAZ is used to form an accordant junction network in the watersheds using the digital elevation model properties. It processes a 30-m (or lower) DEM based on the D8 method. The basic watershed unit is produced by overlaying land use (or management), which represents soil planning and practices under human activities, the soils map, and the digital elevation model. Finally, the parameters of soil and vegetation are input under TopWEPP to obtain the simulation results. According to Yüksel et al. (2008), an advantage of GeoWEPP is that it allows users to process digital elevation models, soils surveys, orthophotos, land use maps and precision farming data.

Currently, GeoWEPP interfaces have been developed by means of the "MapServer" web GIS combined with Google Maps and "OpenLayers" technologies to provide significant spatial enhancements (Flanagan et al., 2013).

WEPP has been applied to several regions around the world for runoff and sediment yield predictions from agricultural (Defersha; Melesse; McClain, 2012; Kim et al., 2009; Maalim et al., 2013; Meghdadi, 2013; Pandey et al., 2008; Pieri et al., 2007; Yu, Zhang; Niu et al., 2009) and forested areas (Dun et al., 2009, 2013; Elliot, 2013; Elliot; Robichaud, 2011). In Brazil, the performance of WEPP has been evaluated, comparing it against RUSLE and USLE models (Amorim et al., 2010). These cited authors showed that GeoWEPP has produced better performance when compared with other models, according to statistical indicators taking into consideration.

Jong van Lier et al. (2005) applied an erosion model (Erosion database interface - EDI) (Ranieri et al., 2002) running GeoWEPP in a watershed with 1,990 ha, in southeastern Brazil, whose land-use was distributed mainly into sugarcane, forest, and pasture. The results showed a successful use of GeoWEPP for prediction of spatially soil erosion and runoff with georeferenced maps as the model's outputs for this hydrological unit.

Despite that the WEPP model has been developed for US pedological and weather conditions, it can successfully be applied in other regions, Brazil included. However, we need to consider carefully the parameters that the model requires as these are poorly determined under field conditions for tropical soils as well as new equations to estimate such values based on soil properties under the tropical and subtropical conditions (Reichert; Norton, 2013).

Nunes and Cassol (2008) showed that the use of soil sand and clay contents, as suggested by the WEPP model, has proved that they are not adequate to estimate the interrill soil erodibility in Oxisols with different clay contents in the State of Rio Grande do Sul, Brazil. Machado et al. (2003) adapted files on 
climate, precipitation, soil, slope gradient and ramp length to run the WEPP model in the region of Agudos, São Paulo State, aiming to elaborate a model suited to the Brazilian forest conditions. Based on theirs results, the WEPP was not properly calibrated for this location, requiring some adaptations and characterization of soil properties required by the model for the tropical soils found in Brazil. In this sense, we understand that there are many studies that need to be carried out related to calibration and validation of soil erosion/hydrology models developed based on conditions and soil from other regions, which have presented significant different behavior under Brazilian geomorphological conditions.

\section{Lavras Simulation of Hydrology (LASH)}

\section{Overview of the model}

A team of researchers have worked in the development of the Lavras Simulation of Hydrology (LASH) model since 2008 in order to make available a conceptually-based hydrological model to estimate stream flows in tropical and subtropical watersheds. However, when the researchers first discussed the model structure, they drew the conclusion that the great challenge would be the necessity of developing a model compatible with the reality of developing countries in terms of both hydrological processes and lack of data base availability. The first applications of LASH to Brazilian watersheds were reported in the studies of Mello et al. (2008), who employed the model in a semi-distributed and lumped approach, and of Beskow et al. (2011) who applied LASH in its grid-cell spatially distributed approach.

The soil-water balance equation is the most fundamental concept in the LASH structure regardless of its spatial and temporal discretization. This equation is used to update the current soil water storage value $\left(A_{t}\right)$ at each time step (TS) and in each hydrological response unit (HRU) (watershed, subwatershed or grid cell). It takes into account the main hydrological processes (also referred to as components) of interest at watershed scale: rainfall (R), interception of rainfall (IR), evapotranspiration (ET), infiltration (I), capillary rise $(\mathrm{CR})$, surface runoff $\left(\mathrm{D}_{\mathrm{S}}\right)$, sub-surface runoff $\left(D_{S S}\right)$, and base flow $\left(D_{B}\right)$. All of these hydrological processes have their values updated at each time step and for every HRU where there is a specific algorithm for each of them. It is worthwhile to mention that there is an interrelationship among different components.

ET is estimated using the Penman-Monteith equation (Allen et al., 1998). Its usage in LASH is intended to estimate crop evapotranspiration considering vegetationrelated parameters such as height, albedo, leaf area index (LAI), stomatal resistance, and aerodynamic resistance, besides the effective rooting depth. Rainfall is stored on the vegetation cover until maximum interception storage $\left(\mathrm{I}_{\max }\right)$ is reached, which is calculated for each HRU as a linear function of LAI. LASH considers the interception reservoir in which it is emptied after each time step as a function of ET ratio. The Penman-Monteith equation is applied for the water intercepted by vegetation separately from the water stored in the soil when the interception reservoir cannot hold any more water, rainfall reaches soil surface directly; otherwise, the rainfall depth that reaches soil surface is reduced by LASH taking into account how much water this reservoir still can store.

The runoff is divided into three components, known as reservoirs:

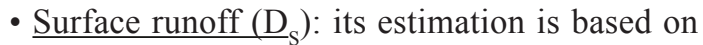
the Curve Number method - Soil Conservation Service modified by Mishra et al. (2003). This method requires information on $\mathrm{R}$, initial abstraction ( $\mathrm{I}_{\mathrm{a}}$ ), maximum potential soil water storage (S), and antecedent soil water storage (M). The main alterations are associated with the approaches employed to compute $\mathrm{I}_{\mathrm{a}}$ and $\mathrm{S}$. The former variable depends on the definition of $\mathrm{S}, \mathrm{M}$ and initial abstraction coefficient $(\lambda)$, whereas, the latter is derived from information on $\lambda, S, M$, and 5-day antecedent rainfall $\left(\mathrm{P}_{5}\right)$. LASH estimates $\mathrm{I}_{\mathrm{a}}$ and $\mathrm{M}$ in accordance with equations suggested by Mishra et al. (2003); on the other hand, there is no equation to estimate $\mathrm{S}$ since curve number $(\mathrm{CN})$ is not used in this approach. The $\mathrm{S}$ value of each HRU is updated in every time step from the difference between maximum soil water storage $\left(\mathrm{A}_{\mathrm{m}}\right)$ and At, which is given by the soil water balance equation. In order to estimate $\mathrm{M}$, it is necessary to calculate a parameter related to $I_{a}(\lambda$, which needs to be calibrated. LASH considers the area of each HRU to convert $D_{S}$ into its corresponding surface runoff volume $\left(\mathrm{V}_{\mathrm{S}}\right)$, which in turn is transformed into surface runoff discharge $\left(Q_{S}\right)$ by using the time of concentration and a parameter related to the residence time of water in the surface reservoir $\left(\mathrm{C}_{\mathrm{S}}\right)$. Aiming to convert this runoff depth into discharge, the model considers the time of concentration and another parameter related to the residence time of water in the surface reservoir (Csup) to reduce the uncertainties, which also needs to be calibrated.

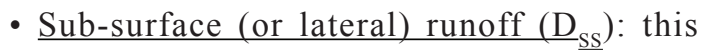
component is estimated using the approach recommended by Rawls et al. (1993), which consists of an adaption of Brooks and Corey equation. In this equation, $D_{S S}$ is 
directly related to hydraulic conductivity of the subsurface reservoir $\left(K_{s s}\right), A_{t}, A_{m}$, minimum soil water storage $\left(\mathrm{A}_{\mathrm{CC}}\right)$ are used to generate $\mathrm{D}_{\mathrm{SS}}$, and a pore-size index (considered constant and equal to 0.4 in the model) is employed. The conversion of $\mathrm{D}_{\mathrm{SS}}$ into sub-surface runoff volume $\left(\mathrm{V}_{\mathrm{SS}}\right)$ is based on the area of each HRU, while calculation of sub-surface runoff discharge $\left(\mathrm{Q}_{\mathrm{SS}}\right)$ depends on the values of $\mathrm{V}_{\mathrm{SS}}$, time of concentration and a parameter related to the residence time of water in subsurface reservoir $\left(\mathrm{C}_{\mathrm{SS}}\right)$.

- Base flow $\left(D_{B}\right)$ : base flow estimation is done in LASH considering the following variables: hydraulic conductivity of the saturated zone $\left(\mathrm{K}_{\mathrm{B}}\right), \mathrm{A}_{\mathrm{m}}, \mathrm{A}_{\mathrm{t}}$, and minimum soil water storage to generate $D_{B}\left(A_{C}\right)$. The calculation of base flow volume $\left(\mathrm{V}_{\mathrm{B}}\right)$ also depends on the area of each HRU, whereas, $V_{B}$ and the residence time $\left(T_{B}\right)$ are used to derive base flow discharge $\left(Q_{B}\right) \cdot T_{B}$ is associated with an aquifer depletion coefficient, which can be obtained from an observed hydrograph if a long drought period is available.

Although it was not mentioned in the above paragraph, the method of linear reservoirs is employed in LASH model to transform the runoff volume of each component into the respective discharge, thus accounting for the delayed effect within each HRU. Afterwards, streamflow $\left(Q_{t}\right)$ is computed at each time step summing $Q_{S}, Q_{S S}$, and $Q_{B}$ for every HRU. Finally, LASH combines $Q_{t}$ values resulting from different HRUs by using the linear Muskingam-Kunge model to route them through the drainage network in order to consider its accumulation effects on hydrograph behavior. Details about this routing method can be found in several hydrology books.

\section{Calibration of unknown parameters at the watershed scale}

The LASH model has many parameters, which can be calibrated depending on the scenario established by the hydrologist. However, the most common parameters to be calibrated are $\lambda, \mathrm{K}_{\mathrm{SS}}, \mathrm{K}_{\mathrm{B}}, \mathrm{K}_{\mathrm{CR}}, \mathrm{C}_{\mathrm{S}}, \mathrm{C}_{\mathrm{SS}}$, and $\mathrm{C}_{\mathrm{B}}$.

$\lambda$ related to the surface runoff (Qs), and normally varies from 0 to 0.5 (Mishra et al., 2003);

- Kss (mm day $\left.{ }^{-1}\right)$ : hydraulic conductivity of the subsurface soil layer, varying from 0 to 182.4 (Rawls et al., 1993);

- $\mathrm{Kb}\left(\mathrm{mm}\right.$ day $\left.^{-1}\right)$ : hydraulic conductivity of the saturated zone, varying from 1.3 to 6 (Beskow et al., 2011);
- $\mathrm{K}_{\mathrm{CR}}\left(\mathrm{mm}\right.$ day $\left.^{-1}\right)$ : maximum flow returning to soil by capillary rise, varying from 0 to 5 (Beskow et al., 2011);

- Csup and Css: response time parameters related to residence time on the respective reservoirs, and Csup is lesser than Css.

From the work of Beskow et al. (2011) and Beskow, Mello and Norton (2011), the LASH model now works within a GIS environment, making it a distributed model by cells. Each step described before is run over a cell whose size will be defined by the users, as presented in the following figure (Figure 2), elaborated by Beskow et al. (2011).

Having this spatial reference for the LASH model application, Beskow et al. (2011) and Beskow, Mello and Norton (2011) developed a mathematical procedure for its calibration:

- One-factor-at-a-time (OAT): this assessment is applied to identify the most important parameters, reducing the number of model runs. Basically, this procedure allows the identification of the most sensitivity parameters.

- Generalized Likelihood Uncertainty Estimation (GLUE): this procedure is used in LASH to quantify the uncertainties in the prediction of output variables taking into account Monte Carlo simulation, which generates a cumulative probability distribution (normal probability distribution) as some parameters have significant uncertainties and this procedure narrowed their boundaries. Thus, the model is run considering each one of the parameters having a statistic of precision as the target, normally, the NashSutcliff coefficient $\left(\mathrm{C}_{\mathrm{NS}}\right)$.

Recently, the LASH model received a new computational module known as "ArcLASH", which was structured in GIS environment, specifically ArcGIS, aiming to support the automatic processing of the spatial data applied in the LASH, including soils, land-use and the drainage network. ArcLASH generates drainage network, soils and land-use maps within the LASH environment, avoiding the users to make a mistake that normally occurs due to different coordinates system, with errors accumulating because of the Digital Elevation Model references, among others.

In Table 1, we can see some applications of LASH model for tropical and sub-tropical watersheds. 


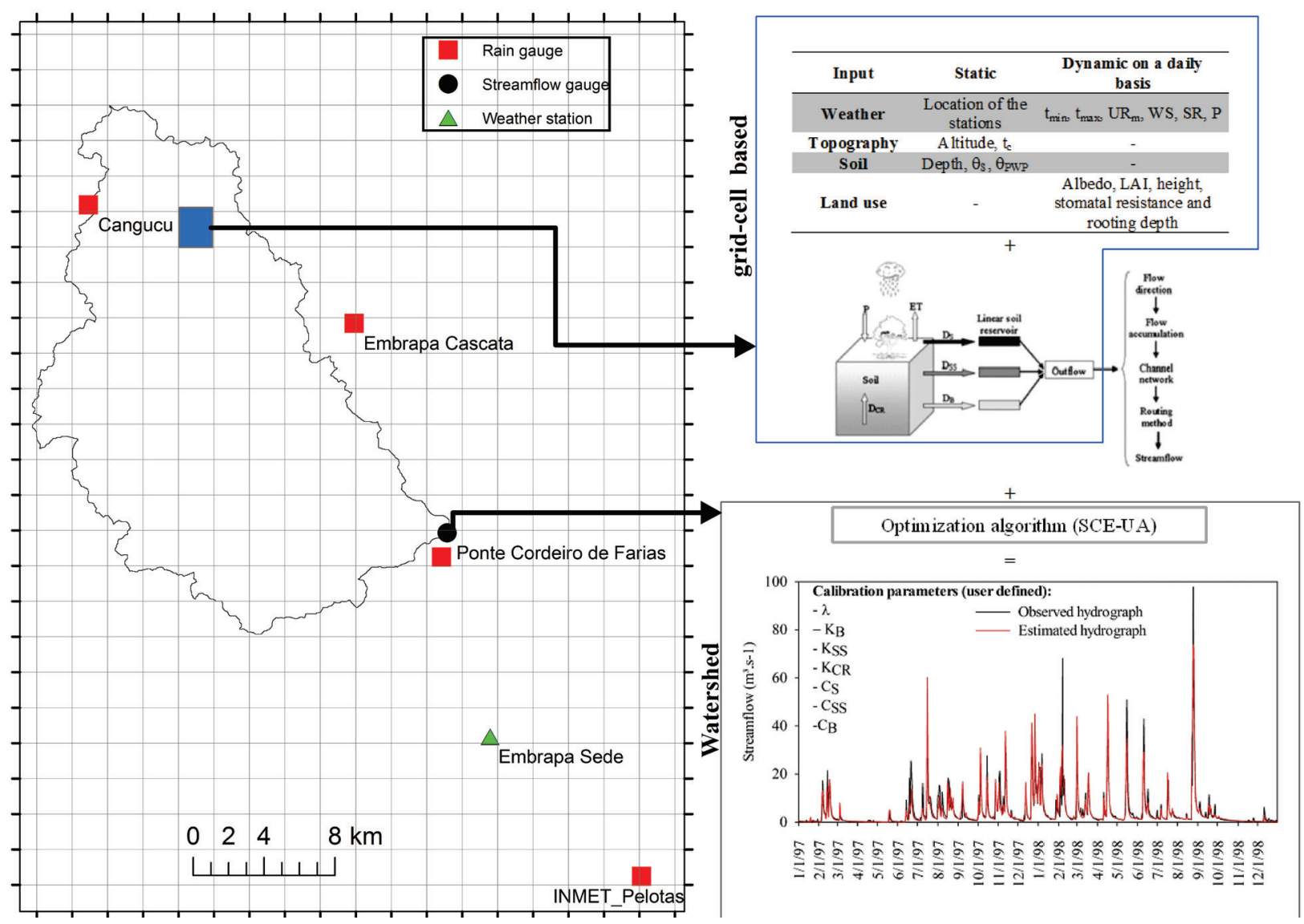

Figure 2: Setup of the LASH for its grid-cell version based on spatial distribution.

Table 1: Main findings by LASH model to simulate streamflows in Brazilian watersheds.

\begin{tabular}{|c|c|c|c|c|}
\hline Watershed/location & Main features & $\begin{array}{l}\text { Calibration } \\
\text { CNS (daily } \\
\text { time step) }\end{array}$ & $\begin{array}{l}\text { Validation } \\
\text { CNS (daily } \\
\text { time step) }\end{array}$ & References \\
\hline $\begin{array}{l}\text { Jaguara Creek/ } \\
\text { Southern Minas Gerais }\end{array}$ & $\begin{array}{l}\text { Dominated by Latosols/Subtropical } \\
\text { Climate (Cwa)/Area: } 32 \text { km2 }\end{array}$ & 0.82 & 0.76 & $\begin{array}{l}\text { Beskow et } \\
\text { al. (2011) }\end{array}$ \\
\hline $\begin{array}{c}\text { Grande River/Southern } \\
\text { Minas Gerais }\end{array}$ & $\begin{array}{l}\text { Dominated by Cambisols/Subtropical } \\
\text { climate (Cwa-Cwb)/Area: } 2085 \text { km2 }\end{array}$ & 0.81 & 0.78 & $\begin{array}{l}\text { Viola et al. } \\
\quad(2014)\end{array}$ \\
\hline $\begin{array}{l}\text { Aiuruoca River/ } \\
\text { Southern Minas Gerais }\end{array}$ & $\begin{array}{l}\text { Dominated by Cambisols/Subtropical } \\
\text { climate (Cwb)/Area: } 2095 \text { km2 }\end{array}$ & 0.76 & 0.78 & $\begin{array}{l}\text { Viola et al. } \\
\quad(2014)\end{array}$ \\
\hline $\begin{array}{c}\text { Lontra River/Northern } \\
\text { Tocantins }\end{array}$ & $\begin{array}{l}\text { Argisols and Fluvic Neools/Tropical } \\
\text { climate (Aw)/Area: } 3470 \text { km2 }\end{array}$ & 0.74 & 0.75 & $\begin{array}{l}\text { Viola et al. } \\
\quad(2012)\end{array}$ \\
\hline $\begin{array}{l}\text { Verde River/Southern } \\
\text { Minas Gerais }\end{array}$ & $\begin{array}{l}\text { Latosols and Cambisols/Subtropical } \\
\text { climate (Cwb)/Area: } 4178 \mathrm{~km} 2\end{array}$ & 0.80 & 0.83 & $\begin{array}{l}\text { Viola et al. } \\
\quad(2014)\end{array}$ \\
\hline $\begin{array}{l}\text { Sapucaí River/Southern } \\
\text { Minas Gerais }\end{array}$ & $\begin{array}{l}\text { Latosols and Cambisols/Subtropical } \\
\text { climate (Cwb)/Area: } 7325 \text { km2 }\end{array}$ & 0.85 & 0.83 & $\begin{array}{l}\text { Viola et al. } \\
\quad(2014)\end{array}$ \\
\hline
\end{tabular}




\section{Soil and Water Assessment Tool (SWAT)}

SWAT has been one of the most applied models around the world. It was developed by the USDA-ARS Grassland, Soil and Water Research Laboratory, in Temple, Texas, USA (Arnold et al., 1998). SWAT was assembled by the combination of other models, like Simulator for Water in Rural Basins (SWRRB) (Arnold et al., 1990), Routing Outputs to Outlet (ROTO) (Arnold; Williams; Maidment, 1995), Chemicals, Runoff and Erosion from Agricultural Management Systems (CREAMS) (Knisel, 1980), Groundwater Loading Effects on Agricultural Management Systems (GLEAMS) (Leonard et al, 1987) and Erosion-Productivity Impact Calculator (EPIC) (Williams; Jones; Dyke, 1984).

According to Neitsch et al. (2005), SWAT is based on two approaches: simulation of the hydrological cycle (with discharges as main output), sediment transportation and water quality on the surface, and routing of these elements throughout the sub-basins, which are shared into Hydrologic Response Unit (HRU), and then, routing to the main drainage channels until the basin's outlet. For simulation of the hydrological cycle elements, SWAT works with different soil layers, which are defined by the users.

Suking to simulate the components of the streamflows, SWAT is structured by the following systems:

- Surface Runoff: this component is simulated based on CN-SCS or Green \& Ampt infiltration methods. $\mathrm{CN}$ consists of a parameter that needs to be calibrated, while Green \& Ampt infiltration method requires sub-daily precipitation data; time of concentration of the sub-basins is also used to convert the surface runoff depth into discharge. However, for estimating the peak discharges, SWAT employs the rational method.

- Sub-surface runoff: water infiltrated that reach layers below the root system is stored, and return to the downstream units as lateral (subsuperficial) streamflow. In order to proceed with this simulation, SWAT uses a kinetic wave model for mass balance, which requires the following properties: soil moisture at field capacity for the considered soil layer, soil saturation capacity, soil saturated hydraulic conductivity, steepness of the hydrological unit and drainable porosity.

- Groundwater flow: SWAT simulates two types of aquifers: shallow and deep. However, for estimation of the base flow component, the model considers only the shallow aquifer contribution. For that, the hydrograph coefficient of depletion is needed as well as the distance between water basin divisor and the main stream channel, besides hydraulic conductivity of the aquifers.

- Evapotranspiration: evaporation and transpiration are calculated separately by SWAT. The model estimates the evaporation from soils and transpiration from plants. SWAT simulates both evaporation and transpiration by means of the Penman-Monteith equation, considering some physiological plants parameters and a coefficient given by a threshold established by the soil moisture. In addition, SWAT considers water movement to the unsaturated adjacent layers as a function of the water demand by evapotranspiration. This process is important for watersheds with the saturated zone close to the surface and/or whether there are predominant plants with deeper root systems (it is known as "revap" in the model structure). In addition to the Penman-Monteith equation, the users can also choose other ET equations, like Hargreaves (Hargreaves; Samani, 1985) and Priestley and Taylor (Priestley; Taylor, 1972).

- Plant growth: SWAT simulates the plant growth through a simplified version of the Environmental Policy Integrated Climate model (EPIC), developed by Williams (1995), which considers the heat units (or growing Degree-Day) for each specie considered.

- Sediment transport: SWAT simulates the soil erosion and sediment transport throughout the drainage channels of the watershed. Firstly, the model uses the Modified Universal Soil Loss Equation (MUSLE), which is run at each HRU. For this purpose, SWAT requires the soil erodibility values for each soil type from the user. For MUSLE's C-factor, the model employs the equations proposed by Wischmeier and Smith (1978) and Arnold and Williams (1995), which are based on a minimum value of $\mathrm{C}$-factor for the respective HRU and the quantity of residues on the ground. For propagation of the sediments by the channels, SWAT considers two physical processes: sedimentation (deposition) and transportation, simultaneously. For the first, Stokes' law is considered based on the maximum velocity of the water on the channel. This calculation is carried out at the sub-basin level. Thus, the maximum 
concentration that can be transported by the channels $\left(\mathrm{conc}_{\text {sedmax }}\right)$ is calculated adjusting the potential equation as a function of two parameters and maximum velocity of water on the channel. If conc $_{\text {sedmax }}$ is lesser than the sediment load estimated by MUSLE the sediment transport will be predominant.

The streamflows are routed in the drainage network using the Variable Storage method, developed by Williams (1969). This method considers a trapezoidal section for the channel and the velocity of water estimates by Manning equation. However, the model can also uses the Muskingham routing method.

SWAT is classified as a semi-distributed model, with the watershed divided into sub-basins. These subbasins are parameterized by the Hydrologic Response Units (HRU), which are defined by the users as a function of several combinations between land use, soil type and slope. This spatial sub-divisions allow the model to better be calibrated as well as to generate outputs spatially distributed by sub-basins or even by hydrologic units. Thus, the streamflows are estimated for each HRU and then routed into the drainage network, for which a hydrologically consistent Digital Elevation Model is necessary.

\section{SWAT calibration}

In latest versions, the calibration/uncertainty analyses procedures for SWAT are carried out in an integrated platform. The SWAT-CUP is a standalone program that links to SWAT's output text files set, which integrates five different optimization algorithms: Sequential Uncertainty Fitting (SUFI-2) (Abbaspour;
Johnson; van Genuchten, 2004; Abbaspour et al., 2007), Generalized Likelihood Uncertainty Estimation (GLUE) (Beven; Binley, 1992), Parameter Solution (ParaSol) (Van Griensven; Meixner, 2006), Markov chain Monte Carlo (MCMC) (e.g., Kuczera; Parent, 1998; Marshall; Nott; Sharma, 2004; Vrugt et al., 2003), and Particle Swarm Optimization (PSO) (Zhang et al. 2015).

Among them, the SUFI-2 algorithm stands out due to its capability to account for all sources of uncertainty on the parameter ranges such as uncertainty in driving variables (e.g., rainfall), conceptual model, parameters, and measured data. The algorithm tries to capture most of the measured data within the $95 \%$ prediction uncertainty (95PPU) calculated at the $2.5 \%$ and $97.5 \%$ levels of the cumulative distribution of an output variable obtained through Latin hypercube sampling.

When acceptable values of goodness of fit indices are reached, then the parameter uncertainties are considered the calibrated parameter ranges and the best simulation is calculated. After the automatic calibration, the parameters of the best simulation can be modified, manually, by: replacing the parameter previously calibrated; adding an absolute value to the calibrated parameter; and relative change, which implies in a correction factor of the parameter. Table 2 presents parameters that normally have been calibrated in the SWAT applications to simulate streamflows for Brazilian conditions (Andrade; Mello; Beskow, 2013; Pinto et al., 2013).

Table 3 summarizes some results from SWAT application to simulate streamflows for Brazilian watersheds.

Table 2: The most sensitive SWAT parameters calibrated for Brazilian basins.

\begin{tabular}{ccc}
\hline Process & Parameters & Description \\
\hline Soil-water & SOL_AWC $(\mathrm{mm}$ mm-1) & Soil water storage \\
interaction & SOL_K $(\mathrm{mm}$ day-1) & Soil saturated hydraulic conductivity \\
& SOL_Z $(\mathrm{mm})$ & Soil layers \\
& ALPHA_BF & Hydrograph recession constant \\
& GWQMN $(\mathrm{mm})$ & Shallow aquifer threshold level for base flow \\
GW_DELAY (day) & Groundwater delay time \\
& GW_REVAP & Ascension water to saturated zone coefficient \\
& ESCO & Coefficient for evaporation of the water from the soils \\
RCHRG_DP & Coefficient to water percolation to deeper aquifers \\
Surface runoff & CN2 & Initial Curve-Number for soil moisture II \\
& CH_N2 & Manning hydraulics coefficient \\
& SURLAG (day) & Coefficient for surface runoff propagation \\
\hline
\end{tabular}


Table 3: Some results from the SWAT model application to simulate streamflows for Brazilian watersheds.

\begin{tabular}{|c|c|c|c|c|}
\hline Watershed/location & Main features & $\begin{array}{l}\text { Calibration } \\
\mathrm{C}_{\text {NS }} \text { (daily } \\
\text { time step) }\end{array}$ & $\begin{array}{l}\text { Validation } \\
\text { C }_{\text {NS }} \text { (daily } \\
\text { time step) }\end{array}$ & References \\
\hline $\begin{array}{c}\text { Jaguara Creek/ } \\
\text { Southern Minas Gerais }\end{array}$ & $\begin{array}{l}\text { Dominated by Latosols/Subtropical } \\
\text { climate (Cwa)/Area: } 32 \mathrm{~km}^{2}\end{array}$ & 0.66 & 0.87 & $\begin{array}{l}\text { Andrade, Mello and } \\
\text { Beskow (2013) }\end{array}$ \\
\hline $\begin{array}{l}\text { Lavrinha Creek/ } \\
\text { Southern Minas Gerais }\end{array}$ & $\begin{array}{l}\text { Dominated by Cambisols/Subtropical } \\
\text { climate (Cwb)/Area: } 6.7 \mathrm{~km}^{2}\end{array}$ & 0.81 & 0.79 & Pinto et al. (2013) \\
\hline $\begin{array}{l}\text { Marcela Creek/ } \\
\text { Southern Minas Gerais }\end{array}$ & $\begin{array}{l}\text { Dominated by Latosols/Subtropical } \\
\text { climate (Cwa)/Area: } 4.80 \mathrm{~km}^{2}\end{array}$ & 0.71 & 0.46 & $\begin{array}{l}\text { Mello Neto et al. } \\
\text { (2014) }\end{array}$ \\
\hline $\begin{array}{l}\text { Paraopeba River/ } \\
\text { Center Minas Gerais }\end{array}$ & $\begin{array}{l}\text { Latosols and Cambisols/Tropical climate } \\
\text { (Aw)/Area: } 10222 \mathrm{~km}^{2}\end{array}$ & 0.77 & 0.76 & $\begin{array}{l}\text { Durães, Mello and } \\
\text { Naghettini (2011) }\end{array}$ \\
\hline $\begin{array}{l}\text { Galo Creek/Espírito } \\
\text { Santo }\end{array}$ & $\begin{array}{l}\text { Latosols/Subtropical-Tropical climate } \\
\text { (Cwa)/Area: } 943 \mathrm{~km}^{2}\end{array}$ & 0.65 & 0.70 & Pereira et al. (2014) \\
\hline $\begin{array}{l}\text { Sapucaí River/ } \\
\text { Southern Minas Gerais }\end{array}$ & $\begin{array}{l}\text { Latosols and Cambisols/Subtropical } \\
\text { climate (Cwb)/Area: } 7325 \mathrm{~km}^{2}\end{array}$ & 0.77 & - & Durães et al. (2014) \\
\hline
\end{tabular}

\section{Distributed Hydrology Soil Vegetation Model (DHSVM)}

The DHSVM was developed in the beginning of 1990 's by the University of Washington, USA. Its first application was concentrated in mountainous catchments located in Northwestern USA, representing the hydrology, the weather and the vegetation of temperate regions (Wigmosta; Vail; Lettenmaier, 1994). Afterwards, other studies in USA have contributed for the consolidation of the model, highlighting Bowling and Lettenmaier (2001) and Doten et al. (2006). After that, DHSVM has been applied in other countries, like Canada (Whitaker et al., 2003), northern Taiwan (Chu et al., 2010), Japan (Yoshitani et al., 2009) and Brazilian Amazon Forest (Cuartas et al., 2012).

DHSVM was initially designed for mountainous regions and has been applied to different research purposes, such as:

- to model and analyze a catchment's hydrology (Wigmosta; Vail; Lettenmaier, 1994; Safeeq; Fares, 2012);

- to evaluate the impacts from climate change on water resources (Leung; Wigmosta, 1999; Cuo et al., 2009; Dickerson-Lange; Mitchell, 2014); and

- to forecast the hydrological regime in a catchment as result from land-use changes, especially deforestation/afforestation influences in the hydrological cycle (Thanapakpawin et al., 2007; Cuo et al., 2008).

Shortly, DHSVM is a parametric physical based distributed model, and runs aiming to represent the effects of topography, soil and plant on the different water fluxes in a watershed, which is derived from a Terrain Digital Model (TDM). Thus, DHSVM takes into account spatial variability and the heterogeneity of each grid cell throughout the watershed basin.

\section{Model Description}

The model runs over a grid of cells whose horizontal resolution varies depending on the Terrain Digital Model and the size of basin. This resolution has varied from 5 to $30 \mathrm{~m}$ to smaller basins (up to $100 \mathrm{~km}^{2}$ ) and $100 \mathrm{~m}$ for the others (from 100 to $10,000 \mathrm{~km}^{2}$ ). According to the temporal resolution of the weather data sets, which can be lower than a daily time step, the model gives a simultaneous solution to water and energy balance equations for each cell. These computational cells are hydrological connected through the sub-surface and surface flows. In addition, the topographical characterization is taken into consideration to control the absorbed solar radiation, to describe the orographic effect on the precipitation pattern, the effects on air temperature and on the dynamics of water throughout the basin. It is worthily to mention that the vegetation parameters and soil properties are also distributed by cells.

DHSVM was structured based on the following modules (Wigmosta; Vail; Lettenmaier, 1994):

- two layers of the canopy to estimate evapotranspiration, which is estimated based on Penman-Monteith equation;

- multi-layers for soils: the soil surface receives water from throughfall, wet saturated canopy, 
stemflow and from neighboring cells' streamflow. Maximum infiltration rate is determined based on the maximum quantity of water that can be infiltrated at each time step and the water movement on unsaturated soils is simulated considering multilayers and each layer of vegetation can extract water from one or more soil layers. Darcy Law simulates water percolation through soil layers by means of Brooks-Corey equation to estimate hydraulic conductivity;

- sub-surface and surface streamflows: these water balance components are estimated based on mechanisms for saturation and infiltration excess (infiltration-rainfall excess relationship); and

- routing streamflows throughout the drainage network: this phase of the hydrological cycle is run by a linear-reservoir routing (Wigmosta; Vail; Lettenmaier, 1994).

\section{Highlight Applications}

In Table 4, a list of some remarkable applications of the DHSVM along with the most important features of the respective study, are presented.

\section{Annualized Agricultural Non-Point Source (AnnAGNPS)}

AnnAGNPS model has been developed through a partnership between the United States Department of Agriculture (USDA), Agricultural Research Service (ARS) and USDA Natural Resources Conservation Service (NRCS) (Bingner; Theurer, 2005; United States Departement of Agriculture-Agricultural Research Service-Usda-Ars, 2006; Yuan; Bingner; Rebich, 2001). AnnAGNPS is a distributed-parameter, continuoussimulation, watershed-scale model and is an expansion of the AGNPS (Young et al., 1989) model, which was originated from the development of the ANSWERS Model (Beasley; Huggins; Monke, 1982; Griffin et al., 1988). AnnAGNPS model was developed to analyze and to provide estimates of runoff with primary emphasis upon non-point source pollutant loadings from agricultural watersheds and to compare the effects of various conservation alternatives ( $\mathrm{Li}$ et al., 2015; Zuercher; Flanagan; Heathman, 2011).

The basic modeling components are hydrology, sediment, nutrient, and pesticide transport (Pease; Oduor; Padmanabhan, 2010). Within the model, runoff using the SCS curve number equation is calculated (United States Departement of Agriculture-Soil Conservation Service-Usda-Scs, 1986) and modified daily based upon tillage operations, soil moisture, and crop stage (Chahor et al., 2014; Fares, 2008). Water erosion is predicted with Revised Universal Soil Loss Equation (RUSLE) (Renard et al., 1997) that was modified to be implemented at the watershed scale in AnnAGNPS (Chahor et al., 2014; Fares, 2008). Evapotranspiration is a function of potential evapotranspiration, calculated using the Penman-Monteith equation and soil-water content (Fares, 2008). AnnAGNPS uses a GIS interface and physical characteristics of watersheds to provide modeling opportunities for areas with limited data (Fares, 2008; Li et al., 2015).

The AnnAGNPS model (Bingner; Theurer; Yuan, 2003) has been evaluated for hydrology simulations and water quality prediction worldwide under different land uses and climate conditions (Baginska; Milne-Home; Cornish, 2003; Chahor et al., 2014; Li et al., 2015; Li; Li; Li, 2012; Hua et al., 2012; Licciardello et al., 2007; Parajuli et al., 2009; Polyakov et al., 2007; Shamshad et al., 2008; Shrestha et al., 2006; Taguas et al., 2012; Yuan et al., 2011; Yuan; Bingner; Rebich, 2001). Li et al. (2015)

Table 4: Some highlights of DHSVM applications with respect to the most important features.

\begin{tabular}{|c|c|c|c|c|c|}
\hline References & Basin & TDM & Area $\left(\mathrm{km}^{2}\right)$ & Rainfall monitoring & $C_{N S}$ \\
\hline $\begin{array}{l}\text { Safeeq and } \\
\text { Fares (2012) }\end{array}$ & $\begin{array}{c}\text { Mãkaha basin, } \\
\text { O'ahu island, USA }\end{array}$ & $\begin{array}{l}\text { Resolution: } 10 \mathrm{~m} \\
\text { Elevation: } 1227 \mathrm{~m}\end{array}$ & 24.6 & Three gauges & $0.57 / 0.74 *$ \\
\hline $\begin{array}{l}\text { Cuartas et al. } \\
\text { (2012) }\end{array}$ & $\begin{array}{l}3 \text { sections in Asu } \\
\text { River, Central } \\
\text { Amazon Brazil }\end{array}$ & $\begin{array}{l}\text { Resolution: } 30 \mathrm{~m} \\
\text { Elevation: } 110 \mathrm{~m}\end{array}$ & $\begin{array}{l}0.95 ; 6.58 \\
12.43\end{array}$ & $\begin{array}{l}\text { Five gauges and one } \\
\text { meteorological station }\end{array}$ & $0.14-0.76^{* *}$ \\
\hline $\begin{array}{l}\text { Chu et al. } \\
(2010)\end{array}$ & $\begin{array}{l}\text { Wu-Tu basin, } \\
\text { Taiwan }\end{array}$ & $\begin{array}{l}\text { Resolution: } 75 \mathrm{~m} \\
\text { Elevation: } 42 \mathrm{~m}\end{array}$ & 204 & $\begin{array}{l}\text { Two meteorological } \\
\text { stations }\end{array}$ & $0.74 / 0.79 *$ \\
\hline $\begin{array}{l}\text { Dickerson- } \\
\text { Lange and } \\
\text { Mitchell (2014) }\end{array}$ & $\begin{array}{l}\text { Nooksack Basin, } \\
\text { Washington, USA }\end{array}$ & $\begin{array}{l}\text { Resolution: } 150 \text { m } \\
\text { Elevation: } 3286 \text { m }\end{array}$ & 2000 & $\begin{array}{l}\text { Climate change data sets } \\
\text { from three GCM and one } \\
\text { meteorological station }\end{array}$ & $0.43 / 0.56^{*}$ \\
\hline
\end{tabular}

CNS: Nash-Sutcliffe coefficient; GCM: Global Circulation Model; *Calibration/validation; **Coefficient variation. 
presented results from an application of the AnnAGNPS model simulating losses nutrients by runoff in a typical small watershed in China. The estimated runoff data for the 2005-2009 and 2010-2013 years were used to calibrate and validate the annual runoff. Nash-Sutcliffe coefficient of model efficiency and coefficient of determination $\left(\mathrm{R}^{2}\right)$ values for the calibration and validation runoff were both 0.96 for calibration and 0.97 for the validation period. Observed nutrient data from July 2008 to September 2009 and December 2012 to December 2013 were used to calibrate and validate the monthly nutrient load. NashSutcliffe efficiency coefficient values for calibration and validation of the monthly nitrogen and phosphorus load were 0.82 and 0.87 , respectively, and the coefficient of determination $\left(\mathrm{R}^{2}\right)$ values for the calibration and simulation of the monthly nitrogen and phosphorus load were 0.86 and 0.88 , respectively. Based on these results, the AnnAGNPS model presented an acceptable tool for runoff and nutrient yield estimations at this hydrological site in China.

Pease, Oduor and Padmanabhan (2010) used the AnnAGNPS model at the Pipestem Creek Watershed in North Dakota and found a high degree of accuracy of the model when runoff was modeled, which was demonstrated by the low values of systematic errors obtained from the coefficient of performance.

In tropical conditions, Shamshad et al. (2008) applied the AnnAGNPS model for soil loss estimation and nutrient loading for watersheds in Malaysia. The authors found a good correlation between the predicted and observed data, which suggested that the AnnAGNPS model can be capable of being used as a valuable tool for planning and management of studied watersheds in that country.

It is important to stress the absence of application of the AnnAGNPS model in the Brazilian conditions. Only few works in tropical conditions exemplify the difficulty in obtaining the appropriate number of parameters that are needed in calibration of this model, especially in Brazil, where these type of data have been scarce.

\section{BENEFITS AND USES OF THE MODELS}

In order to model natural systems, like hydrological and sediment cycles, many challenges have been faced by the scientists. Models have been the most feasible (lowest cost/benefit ratio) way to predict impacts from human actions on the nature, and then to supply information to managers to prevent extreme impacts from weather on harvesting, flooding, landslides, historical droughts, among other outputs. In addition, models can be very useful to generate datasets that allow the adequate water resources management by means of evaluating different scenarios for water uses, availability of water for the future, and generating studies for an adequate hydraulic structures and spills to control excessive runoff and/or sediment transport. Besides, water quality as another of models' output, is fundamental for the natural resources management and planning, especially for drinking water.

Many studies have been conducted at the watershed level simulating the impacts on hydrology (water quality, erosion and sediment transport) from removal of the native vegetation (e.g., forest) and then, evaluating the impacts on water quality. Based on these results, it is possible to evaluate how much the society will need to pay for protection of headwaters streams aiming to preserve the quality and quantity of water. This process is known as "ecological services", in which models have been useful in evaluating the hydrological cycle and quantifying its effects.

With the development of geospatial technologies, the use and application of hydrology models have had a new and significant improvements not only to solve hydraulic engineering problems but also as a powerful tool to support the solutions for environmental issues, like the groundwater recharge process, soil erosion and transport, eco-hydrology interactions, among others.

The results from hydrological and erosion models simulation of processes have been the primary information for land-use planning in the watershed basins, especially to better understanding how the hydrological cycle, soils and vegetation interact between themselves. Demonstrating the possible impacts (negatives or positives) generated by removal of species or changing soil management from agricultural to forestry and livestock activities has helped to understand how better to conserve the environment. Based on the advent of new computational technologies, the outputs from models can provide a much better understanding by scientists and land managers, and consequently, give more support for the actions of the field level engineers.

One of the most significant state-of-art studies involves hydrologic models to simulate climate change impacts on the hydrology of watershed basins, allowing the discussion about how the hydrological cycle, water erosion and sediment transport can be affected in the future. In this context, for example, Viola et al. (2015) applied LASH and Eta-CPTEC HadCM3 models for headwater region of Mantiqueira Range, southern Minas Gerais, and verified that the climate change could alter the base flow regime of the basins, which can compromise the water yield on 
the region which is the most important headwaters of the southeastern Brazil. In addition, floods will become more severe in the region due to excessive concentration of rainfalls during the summer. Another study in the context of RUSLE applicability was developed by Mello et al. (2015) in which they found a significant increase in erosion rates towards the end of century for the headwaters of Grande River basin, Brazil.

\section{FINAL CONSIDERATIONS}

The use of hydrologic models has been a widely effective tool in order to support decision makers dealing with watersheds related to several economic and social activities, like public water supply, energy generation, and water availability for irrigation, among others. The application of these tools is based on the understanding of the hydrological cycle and its prediction. GIS and remote sense tools, searching to obtain a distributed model in both space and time, have supported the models, aiming to reduce the uncertainties and providing basis for simulation of different scenarios in the watersheds.

Therefore, hydro-sedimentological models simulations consist of a scientific process that should be conducted having in mind a rigorous calibration/ validation process, which will allow their applications for a specific hydrology unit with lesser uncertainty. In this sense, one of the most relevant state-of-art of knowledge in the earth natural sciences is associated to the simulation of different impacts from both climate and land-use change scenarios on the hydrology, erosion and sediment transport in the watersheds.

Nevertheless, the majority of models have presented limitations mainly related to simulate adequately the long-term impacts from different landuses changes. As an example, the impacts from pasture instead of native forest (or vice-versa) even after a very adequate performance during the calibration and validation process, need to be considered taking into consideration the limitations for modeling dynamically the infiltration process as it is directly influenced by the respective land-use throughout the time. These limitations are associated with simplifications adopted in the models' structure, such as:

to simulate different land-uses, the modelers have changed the real use by another one based only on the parameters related to plants, like aerodynamic and stomatal resistances, leaf area index, root depth, deficit water vapor pressure and others more related to the physiology of the plants; thus, the impact on the water budget simulated by the model will be more related to evapotranspiration;

the inability of the models to describe physically the real life interactions, mainly considering the time, of the plants impacts on the surface and vadose zone, generates new processes which are not captured by the model. One of these processes is related to the soil infiltrability behavior after deforestation. There are a number of studies demonstrating the role of native forest (litter and biological activities) on the preferential flows formation in the soil profile, which has promoted much greater infiltration capacity of the soils. These preferential flows are formed from micro-to macro-scales in the watersheds and influence the overall water budget. The models cannot simulate this process adequately as this interaction (soil - biological activities) is very uncertain to be modeled. Thus, the water budget outputs, mainly those related with base flow, will not be adequately simulated, conducting to wrong conclusions.

Finally, we understand that the models have been changed and evaluated in a significant manner in recent years, highlighting the use of remote sense, GIS and automatic calibration process, allowing the models to be capable of simulating a given current land-use in the watersheds. However, all hydrology models have almost the same physical structure, which is not enough for simulating problems related to the long-term effects of different land-uses. That is our challenge for the future: to understand entirely the hydrology cycle, e.g., the critical zone, in which the hydrological processes act together from canopy to the bottom of aquifers.

\section{REFERENCES}

ABBASPOUR, K. C.; JOHNSON, A.; VAN GENUCHTEN, M. Th. Estimating uncertain flow and transport parameters using a sequential uncertainty fitting procedure. Vadose Zone Journal, 3(4):1340-1352, 2004.

ABBASPOUR, K. C. et al. Modelling hydrology and water quality in the pre-alpine/alpine Thur watershed using SWAT. Journal of Hydrology, 333(2/4):413-430, 2007.

ALLEN, R. G. et al. Crop evapotranspiration: guidelines for computing crop water requirements. FAO: Rome, 1998, $300 p$.

AMORIM, R. S. S. et al. Avaliação dos modelos de predição da erosão hídrica USLE, RUSLE e WEPP para diferentes condições edafoclimáticas do Brasil. Engenharia Agrícola, 30(6):1046-1059, 2010. 
ANDRADE, M. A.; MELLO, C. R.; BESKOW, S. Simulação hidrológica em uma bacia hidrográfica representativa dos Latossolos na região Alto Rio Grande, MG. Revista Brasileira de Engenharia Agrícola e Ambiental, 17(1):6976, 2013.

ARNOLD, J. G. et al. SWRRB: A basin scale simulation model for soil and water resources management. College Station: Texas A\&M University Press, 1990. 255p.

ARNOLD, J. G.; WILLIAMS, J. R.; MAIDMENT, D. R. Continuostime water and sediment-routing model for large basins. Journal of Hydraulic Engineering, 121(2):171-183, 1995.

ARNOLD, J. G.; WILLIAMS, J. R. SWRRB - A watershed scale model for soil and water resources management. In: SINGH, V.P. (ed). Computer models of watershed hydrology. Water Resources Publications, 1995. p.847-908.

ARNOLD, J. G. et al. Large area hydrologic modeling and assessment: part I. Model development. Journal of the American Water Resources Association, 34(1):73-89, 1998.

BAGINSKA, B.; MILNE-HOME, W.; CORNISH, P. S. Modelling nutrient transport in Currency Creek, NSW with AnnAGNPS and PEST. Environmental Modelling \& Software, 18(89):801-808, 2003.

BEASLEY, D. H.; HUGGINS, L. F.; MONKE, E. J. Modeling sediment yields from agricultural watersheds. Journal of Soil and Water Conservation, 37(2):114-117, 1982.

BESKOW, S. et al. Soil erosion prediction in the Grande River Basin, Brazil using distributed modeling. Catena, 79(1):4959, 2009.

BESKOW, S. et al. Performance of a distributed semi-conceptual hydrological model under tropical watershed conditions. Catena, 86(3):160-171, 2011.

BESKOW, S.; MELLO C. R.; NORTON L. D. Development, sensitivity and uncertainty analysis of LASH model. Scientia Agricola, 68(3):265-393, 2011.

BEVEN, K.; BINLEY, A. The future of distributed models e model calibration and uncertainty prediction. Hydrological Processes, 6(3):279-298, 1992.

BINGNER, R. L.; THEURER, F. D.; YUAN, Y. AnnAGNPS Technical Processes, 2003. Available in: <http://www.ars.usda.gov/ Research/docs.htm?docid=5199>. Access in: Oct 2015.

BINGNER, R. L.; THEURER, F. D. AnnAGNPS technical processes documentation, version 3.2. Oxford, MS, USA: USDA-ARS National Sedimentation Laboratory, 2005.
BOWLING, L. C.; LETTENMAIER, D. P. The effects of forest roads and harvest on catchment hydrology in a mountainous maritime environment. In: M. S. WIGMOSTA, M. S.; BUGES, S. J. Land use and watersheds: human influence on hydrology and geomorphology in urban and forest areas. Washington: American Geophysical Union, 2001. p.145-164.

CHAHOR, Y. et al. Evaluation of the AnnAGNPS model for predicting runoff and sediment yield in a small mediterranean agricultural watershed in Navarre (Spain). Agricultural Water Management, 134(1):24-37, 2014.

$\mathrm{CHU}, \mathrm{H}$. J. et al. Modelling the hydrologic effects of dynamic land-use change using a distributed hydrologic model and a spatial land-use allocation model. Hydrological Processes, 24(18):2538-2554, 2010.

CUARTAS, L. A. et al. Distributed hydrological modeling of a micro-scale rainforest watershed in Amazonia: model evaluation and advances in calibration using the new HAND terrain model. Journal of Hydrology, 462(10):1527, 2012.

CUO, L. et al. Effects of a century of land cover and climate change on the hydrology of the Puget Sound basin. Hydrological Processes, 23(6):907-933, 2009.

CUO, L. et al. Hydrologic prediction for urban watersheds with the Distributed Hydrology-Soil-Vegetation Model. Hydrological Processes, 22(21):4205-4213, 2008.

DEB, S.; SHUKLA, M. K. An overview of some hydrological watershed models. In: SHUKLA, M. K. Soil Hydrology, Land Use and Agriculture: Measurement and Modeling. Wallingford, U.K.: CAB International, 2011. p.75-116.

DEFERSHA, M. B.; MELESSE, A. M.; MCCLAIN, M. E. Watershed scale application of WEPP and EROSION 3D models for assessment of potential sediment source areas and runoff flux in the Mara River basin, Kenya. Catena, 95:63-72, 2012.

JONG VAN LIER, Q. de et al. Runoff mapping using WEPP erosion model and GIS tools. Computers and Geosciences, 31(10):1270-1276, 2005.

DICKERSON-LANGE, S.; MITCHELL, R. Modeling the effects of climate change projections on streamflow in the Nooksack River basin, northwest Washington. Hydrological Processes, 28(20):5236-5250, 2014.

DOTEN, C. O. et al. A spatially distributed model for the dynamic prediction of sediment erosion and transport in mountainous forested watersheds. Water Resources Research, 42(4):W04117, 2006. 
DUN, S. et al. Adapting the Water Erosion Prediction Project (WEPP) model for forest applications. Journal of Hydrology, 366(1-4):46-54, 2009.

DUN, S. et al. Applying online WEPP to assess forest watershed hydrology. Transactions of the ASABE, 56(2):581-590, 2013.

DURÃES, M.; MELLO, C. R.; NAGHETTINI, M. Applicability of the SWAT model for hydrologic simulation in Paraopeba River basin, MG. Cerne, 17(4):481-488, 2011.

DURÃES, M.; MELLO, C. R. Hydrosedimentologic disturbance index applied to watersheds of Minas Gerais state. Ciência e Agrotecnologia, 38(1):61-67, 2014.

EAGLESON, P. S. Dynamic Hydrology. New York: McGraw-Hill 1970, 462p.

ELLIOT, W. J. Erosion processes and prediction with WEPP technology in forests in the northwestern U.S. Transactions of the ASABE, 56(2):563-579, 2013.

ELLIOT, W. J.; P. R. ROBICHAUD. Risk-based erosion assessment: Application to forest watershed management and planning. In: MORGAN, R. P. C., NEARING, M. A. Handbook of Erosion Modelling. Blackwell Publishing Ltd., 2011. p.117-134.

FARES, 2008. Overview of the hydrological modeling of small coastal watersheds on tropical islands. In: FARES, A.; ELKADI, A. I. Coastal Watershed Management. International series on progress in water resources. Southampton: WIT Press, 2008, v.13, p.1-27.

FLANAGAN, D. C.; NEARING, M. A. USDA Water Erosion Prediction Project hillslope and watershed model documentation. NSERL Report No. 10. West Lafayette, Ind.: USDA-ARS National Soil Erosion Research Laboratory, 1995. Available in: <http://www.ars.usda.gov/Research/ docs.htm?docid=18073>. Access in: Oct, 22, 2015.

FLANAGAN, D. C. et al. The water erosion prediction project (WEPP) model. In: HARMON, R. S.; DOE, W. W. Landscape Erosion and Evolution Modeling. Kluwer Academic/Plenum Publishers, New York, 2001, p. 145199.

FLANAGAN, D. C.; GILLEY, J. E.; FRANTI, T. G. Water erosion prediction project: development history, model capabilities, and future enhancements. Transactions of the ASABE 50(5):1603-1612, 2007.

FLANAGAN, D. C. et al. Geospatial application of the Water Erosion Prediction Project (WEPP) model. Transactions of the ASABE, 56(2):591-601, 2013.
FOSTER, G. R.; LANE, L. J. User Requirements: USDA Water Erosion Prediction Project (WEPP). NSERL Report No. 1, USDA ARS National Soil Erosion Research Laboratory, West Lafayette, Indiana, 1987, 43p.

GRIFFIN, M. L. et al. Estimating soil loss on topographically nonuniform field and farm units. Journal of Soil and Water Conservation, 42(3):326-331, 1988.

HARGREAVES, G. H.; SAMANI, Z. A. Reference crop evapotranspiration from temperature. Applied Engineering in Agriculture, 1(2):96-99, 1985.

HUA, L. et al. Assessment of runoff and sediment yields using the AnnAGNPS model in a Three-Gorge Watershed of China. International Journal of Environmental Research and Public Health, 9(5):1887-1907, 2012.

KIM, M. K. et al. Impact of precipitation changes on runoff and soil erosion in Korea using CLIGEN and WEPP. Journal of Soil and Water Conservation, 64(2):154-162, 2009.

KNISEL, W. G. CREAMS: a field scale model for chemicals, runoff and erosion from agricultural management systems. USDASEA Conservation, Research Report 26, 1980. USDA-ARS, Washington, DC, 672p.

KUCZERA, G.; PARENT, E. Monte Carlo assessment of parameter uncertainty in conceptual catchment models: the Metropolis algorithm. Journal of Hydrology, 211(1/4):6985, 1998.

LAFLEN, J. M. et al. WEPP soil erodibility experiments for rangeland and cropland soils. Journal of Soil and Water Conservation, 46(1):39-44, 1991.

LEONARD, R. A.; KNISEL, W. G.; STILL, D. A. GLEAMS: groundwater loading effects of agricultural management systems. Transaction of the ASAE, 30(5):1403-1418, 1987.

LEUNG, L. R.; WIGMOSTA, M. S. Potential climate change impacts on mountain watersheds in the Pacific Northwest. Journal of the American Water Resources Association, 35(6):1463-1471, 1999.

LI, J.; LI, H.; LI, Y. Evaluation of AnnAGNPS and its applications in a semi-arid and semi-humid watershed in Northwest China. International Journal of Environment and Pollution, 49(1-2):62-88, 2012.

LI, Z. et al. Assessment of the AnnAGNPS model in simulating runoff and nutrients in a typical small watershed in the Taihu Lake basin, China. Catena, 133:349-361, 2015. 
LICCIARDELLO, F. et al. Runoff and soil erosion evaluation by the AnnAGNPS model in a small mediterranean watershed. Transactions of the ASABE, 50(5):1585-1593, 2007.

MAALIM, F. K. et al. Modeling the impact of land use changes on runoff and sediment yield in the Le Sueur watershed, Minnesota using GeoWEPP. Catena, 107:35-45, 2013.

MACHADO, C. C. et al. Comparison of erosion rates in forest roads applying the WEPP model (Water Erosion Prediction Project) modified with reference to experimental measurements. Revista Árvore, 27(3):295300, 2003.

MARSHALL, L.; NOTT, D.; SHARMA, A. A comparative study of Markov chain Monte Carlo methods for conceptual rainfall-runoff modeling. Water Resources Research, 40(2):1-11, 2004.

MEGHDADI, A. R. Identification of effective best management practices in sediment yield diminution using GeoWEPP: the Kasilian watershed case study. Environmental monitoring and assessment, 185(12):9803-9817, 2013.

MELLO, C. R.; CURI, N. Hydropedology. Ciência e Agrotecnologia, 36(2):137-146, 2012.

MELLO, C. R. et al. Development and application of a simple hydrologic model simulation for a Brazilian headwater basin. Catena, 75(3):235-247, 2008.

MELLO, C. R. et al. Assessing the climate change impacts on the rainfall erosivity throughout the twenty-first century in the Grande River basin (GRB) headwaters, southeastern Brazil. Environmental Earth Sciences, 73(12):1-16, 2015.

MELLO C. R. et al. Multivariate models for annual rainfall erosivity in Brazil. Geoderma, 202-203:88-102, 2013.

MELO NETO, J. O. et al. Simulação hidrológica escalar com o modelo SWAT. Revista Brasileira de Recursos Hídricos, 19(1):177-188, 2014.

MISHRA, S. K. et al. A modified SCS-CN method: characterization and testing. Water Resources Management, 17(1):37-68, 2003.

MULVANEY, T. J. On the use of self-registering rain and flood gauges in making observations on the relation of rainfall and of flood discharges in a given catchment. Transactions of the Institution of Civil Engineers of Ireland, 4(2):18$33,1850$.

NEITSCH, S. L. et al. Soil and water assessment tool: theoretical documentation - version 2005. SERVICE., G-S. A. W. R. L. - A. R. Texas - USA: 525 p. 2005.
NICKS, A. D.; LANE, L. J.; GANDER, G. A. Weather generator. In: FLANAGAN, D. C.; NEARING, M. A. USDA Water Erosion Prediction Project hillslope and watershed model documentation. NSERL Report No. 10. West Lafayette, Ind.: USDA-ARS National Soil Erosion Research Laboratory, 1995. 2.1-2, 22p.

NUNES, M. C. M.; CASSOL, E. A. Estimativa da erodibilidade em entressulcos de latossolos do Rio Grande do Sul. Revista Brasileira de Ciência do Solo, 32:2839-2845, 2008.

OLIVEIRA, V.A. et al. Soil erosion vulnerability in the Verde River basin, southern Minas Gerais. Ciência e Agrotecnologia, 38(3):262-269, 2014.

PANDEY, A. et al. Runoff and sediment yield modeling from a small agricultural watershed in India using the WEPP model. Journal of Hydrology, 348(3-4):305-319, 2008.

PARAJULI, P. B. et al. Comparison of AnnAGNPSand SWAT model simulation results in USDA-CEAP agricultural watersheds insouth-central Kansas. Hydrological Processes, 23(5):748763, 2009.

PEASE, L. M.; ODUOR, P.; PADMANABHAN, G. Estimating sediment, nitrogen, and phosphorous loads from the Pipestem Creek watershed, North Dakota, using AnnAGNPS. Computers \& Geosciences, 36(3):289-291, 2010.

PEREIRA, D. R. et al. Hydrological simulation using SWAT model in headwater basin in southeast Brazil. Engenharia Agrícola, 34(4):789-799, 2014.

PHILLIP, J. R. Soils, natural science, and models. Soil Science, 151(1):91-98, 1991.

PIERI, L. et al. Using the Water Erosion Prediction Project (WEPP) model to simulate fieldobserved runoff and erosion in the Apennines mountain range, Italy. Journal of Hydrology, 336(1-2):84-97, 2007.

PINTO, D. B. F. et al. Application of the Soil and Water Assessment Tool (SWAT) for sediment transport simulation at a headwater watershed in Minas Gerais state, Brazil. Transactions of the ASABE, 56(2):697-709, 2013.

POLYAKOV, V. et al. Evaluation of a non-point source pollution model, AnnAGNPS, in a tropical watershed. Environmental Modelling \& Software, 22(11):1617-1627, 2007.

PRIESTLEY, C. H. B.; TAYLOR, R. J. On the assessment of surface heat flux and evaporation using large-scale parameters. Monthly Weather Review, 100(2):81-82, 1972. 
RANIERI, S. B. L. et al. Erosion database interface (EDI): a computer program for georeferenced application of erosion prediction models. Computers \& Geosciences, 28(1):661-668, 2002.

RAWLS, W. J. et al. Infiltration and soil water movement. In: MAIDMENT, D. R. Handbook of hydrology. New York: McGraw-Hill, Chap. 5, 1993. p.1-51.

REICHERT J. M.; NORTON L. D. Rill and interrill erodibility and sediment characteristics of clayey Australian vertosols and a ferrosol. Soil Research, 51(1):1-9, 2013.

RENARD, K. G. et al. Predicting soil erosion by water: a guide to conservation planning with the Revised Universal Soil Loss Equation (RUSLE). Washington: USDA, 1993. 384p. (Agricultural Handbook, 703).

RENARD, K.G. et al. Predicting soil erosion by water: a guide to conservation planning with the Revised Universal Soil Loss Equation (RUSLE). Government Printing Office, USDA, 1997.

RENSCHLER, C. S. Designing geo-spatial interfaces to scale process models: the GeoWEPP approach. Hydrological Processes, 17(5):1005-1017, 2003.

SAFEEQ, M.; FARES, A. Hydrologic effect of groundwater development in a small mountainous tropical watershed. Journal of Hydrology, 428/429:51-67, 2012.

SEGURA, C. et al. Potential impacts of climate change on soil erosion vulnerability across the conterminous United States. Journal of Soil and Water Conservation, 69(2):171181, 2014.

SHAMSHAD, A. et al. Applications of AnnAGNPS model for soil loss estimation and nutrient loading for Malaysian conditions. International Journal of Applied Earth Observation and Geoinformation, 10(3):239-252, 2008.

SHRESTHA, S. et al. Evaluation of annualized agricultural nonpoint source model for a watershed in the Siwalik Hills of Nepal. Environmental Modelling \& Software, 21(7):961-975, 2006.

TAGUAS, E. V. et al. Modeling the contribution of ephemeral gully erosion under different soil managements: a case study in an olive orchard microcatchment using the AnnAGNPS model. Catena, 98:1-16, 2012.

TANG, Q. et al. Assessment of soil erosion using RUSLE and GIS: a case study of the Yangou watershed in the Loess Plateau, China. Environmental Earth Science, 73(4):1715$1724,2015$.
THANAPAKPAWIN, P. et al. Effects of landuse change on the hydrologic regime of the Mae Chaem river basin, NW Thailand. Journal of Hydrology, 334(1):215-230, 2007.

UNITED STATES DEPARTEMENT OF AGRICULTURE-SOIL CONSERVATION SERVICE-USDA-SCS. Urban hydrology for small watersheds. Technical release 55, 2nd ed., NTIS PB87-101580. U.S. Department of Agriculture, Soil Conservation Services, Springfield, VA, USA, 1986, 160p.

UNITED STATES DEPARTEMENT OF AGRICULTUREAGRICULTURAL RESEARCH SERVICE- USDA-ARS. 2006. AnnAGNPS - Annualized agricultural non-point source pollution model. Available in: <http://www.ars.usda.gov/ Research/docs.htm?docid=5199>. Access in: Oct 2015.

VAN GRIENSVEN, A.; MEIXNER, T. Methods to quantify and identify the sources of uncertainty for river basin water quality models. Water Science and Technology, 53(1):5159, 2006.

VIOLA, M. R. et al. Impacts of land-use changes on the hydrology of the Grande River basin headwaters, Southeastern Brazil. Water Resources Management, 28(13):4537-4550, 2014.

Modelagem hidrológica em uma sub-bacia hidrográfica do baixo rio Araguaia, TO. Journal of Biotechnology and Biodiversity, 3(3):38-47, 2012.

Assessing climate change impacts on Upper Grande River basin hydrology, southeast Brazil. International Journal of Climatology, 35(6):1054-1068, 2015.

VRUGT, J. A. et al. A shuffled complex evolution Metropolis algorithm for optimization and uncertainty assessment of hydrologic model parameters. Water Resources Research, Washington, 39(8):1-14, 2003.

WHITAKER, A. et al. Application of the distributed hydrology soil vegetation model to Redfish Creek, British Columbia: model evaluation using internal catchment data. Hydrological Processes, 17(2):199-224, 2003.

WIGMOSTA, M. S.; VAIL, L. W.; LETTENMAIER, D. P. A distributed hydrology-vegetation model for complex terrain. Water Resources Research, 30(6):1665-1679, 1994.

WILLIAMS, J. R.; JONES, C. A.; DYKE, P. T. A modeling approach to determining the relationship between erosion and soil productivity. Transaction of the ASAE, 27(1):129-144, 1984. 
WILLIAMS, J. R. Flood routing with variable travel time or variable storage coefficients. Transactions of the ASAE, 12:100-103, 1969.

WILLIAMS, J. R. The EPIC model, 1995. In: SINGH, V. P. Computer Models of Watershed Hydrology. Water Resources Publications, Highlands Ranch, CO, 1995, p.909-1000.

WISCHMEIER, W. H.; SMITH, D. D. Predicting rainfall erosion losses-a guide to conservation planning. Agriculture Handbook No. 537, USDA, Washington, 1978, p. 58.

YOUNG, R. A. et al. AGNPS: A nonpoint-source pollution model for evaluating agricultural watersheds. Journal of Soil and Water Conservation, 44(2):168-173, 1989.

YOSHITANI, J. et al. Atmospheric model-based streamflow forecasting at small, mountainous watersheds by a distributed hydrologic model: application to a watershed in Japan. Journal of Hydrologic Engineering, 14(10):11071118, 2009.

YUAN, Y. et al. Assessing the long term impact of phosphorus fertilization on phosphorus loadings using AnnAGNPS. International Journal of Environmental Research and Public Health, 8(6):2181-2199, 2011.
YUAN, Y.; BINGNER, R. L.; REBICH, R. A. Evaluation of AnnAGNPS on Mississippi Delta MSEA watersheds. Transactions of the ASABE, 44(5):1183-1190, 2001.

YU, X. X.; ZHANG, X. M.; NIU, L. L. Simulated multi-scale watershed runoff and sediment production based on GeoWEPP model. International Journal of Sediment Research, Beijing, 24(4):465-478, 2009.

YÜKSEL, A. et al. Application of GeoWEPP for determining sediment yield and runoff in the Orcan Creek watershed in Kahramanmaras, Turkey. Sensors, 8(2):1222-1236, 2008.

ZHANG, J. et al. The comparative study of multi-site uncertainty evaluation method based on swat model. Hydrological Processes, 29(13):2994-3009, 2015.

ZHANG, X. C.; GARBRECHT, J. D. Evaluation of cligen precipitation parameters and their implication on wepp runoff and erosion prediction. Transactions of the ASAE, 46(2): 311-320, 2003.

ZHOU, P. et al. Effect of vegetation cover on soil erosion in a mountainous watershed. Catena, 75(3):319-325, 2008.

ZUERCHER, B. W.; FLANAGAN, D. C.; HEATHMAN, G. C. Evaluation of the AnnAGNPS model for atrazine prediction in northeast Indiana. Transactions of the ASABE, 54(3):811-825, 2011. 
http://dx.doi.org/10.1590/1413-70542016000200012

\section{ERRATUM}

In the manuscript entitled Agricultural watershed modeling: a review for hydrology and soil erosion processes, published in the volume 40, number 1, page 7, the text Leandro Campos Pinto ${ }^{3}{ }^{3}$ Universidade Federal de Pelotas / UFPel, Pelotas, RS, Brasil (http://www.scielo.br/scielo.php?script=sci_arttext\&pid=S1413-70542016000100007\&lng $=$ en\&nrm=iso\&tlng=en\#aff2), must be replaced by Leandro Campos Pinto ${ }^{4}:{ }^{4}$ Universidade Federal de Lavras/UFLA, Departamento de Ciência do Solo/DCS, Lavras, MG, Brasil. 